\title{
Strategic management for squeezing ground conditions at the Argyle Diamonds block cave project
}

\author{
F. Fernandez Rio Tinto Technology and Innovation, Australia \\ G. Watt Rio Tinto Technology and Innovation, Australia
}

J. Ooi Rio Tinto Technology and Innovation, Australia

\section{Abstract}

A methodology of damage assessment has been elaborated, based on conditions encountered in the Argyle Diamonds Underground Project (ADUP). It has been developed iteratively over a number of months and has been used to comprehensively represent damage conditions as the undercut front advances. Correlation between damage and convergence has been established. The ground support regime that has been implemented at the ADUP to withstand very severe squeezing (Hoek and Marinos, 2000) has produced the outcome that only in limited areas of extreme squeezing (in excess of $20 \%$ convergence) has stripping and rehabilitation been required to enable undercutting operations to continue. This issue highlights the importance of the implementation of adequate guidelines to maintain drive stability and safety during undercutting.

The long-term and strategic implications of correlating damage conditions with convergence and therefore deformation are that a practical predictive model can be developed. This can then be used to forecast the level of damage that is likely to occur in the undercut drives and extraction level drives based on displacement modelling. This model allows an optimised level of support and reinforcement to be designed depending on the predicted damage conditions. Such a 'predictive' model could be used to estimate the optimal level of support and reinforcing (and to establish a realistic budget and schedule for the work); as well as an ongoing tool for forecasting damage conditions (and remedial support and reinforcing) during undercutting and block caving progression.

\section{Introduction}

Rio Tinto's Argyle Diamond Mine is located $150 \mathrm{~km}$ south of Kununurra in the East Kimberley region of Western Australia about 2,300 km northeast of Perth, as is shown in Figure 1.

Argyle Diamonds is the world's largest supplier of diamonds, which has historically produced 25-30 million carats each year from its operations in the remote north of Western Australia. The diamonds produced by Argyle are found in a range of colours including white, champagne, cognac and pink. Argyle's production accounts for approximately one-quarter of the world's natural diamond production. Open cut mining of the main orebody commenced in 1985, and has since produced more than 600 million carats of diamonds, ranging from gem quality to near gem and industrial diamonds. More than $90 \%$ of Argyle's diamonds are destined for the jewellery industry. 


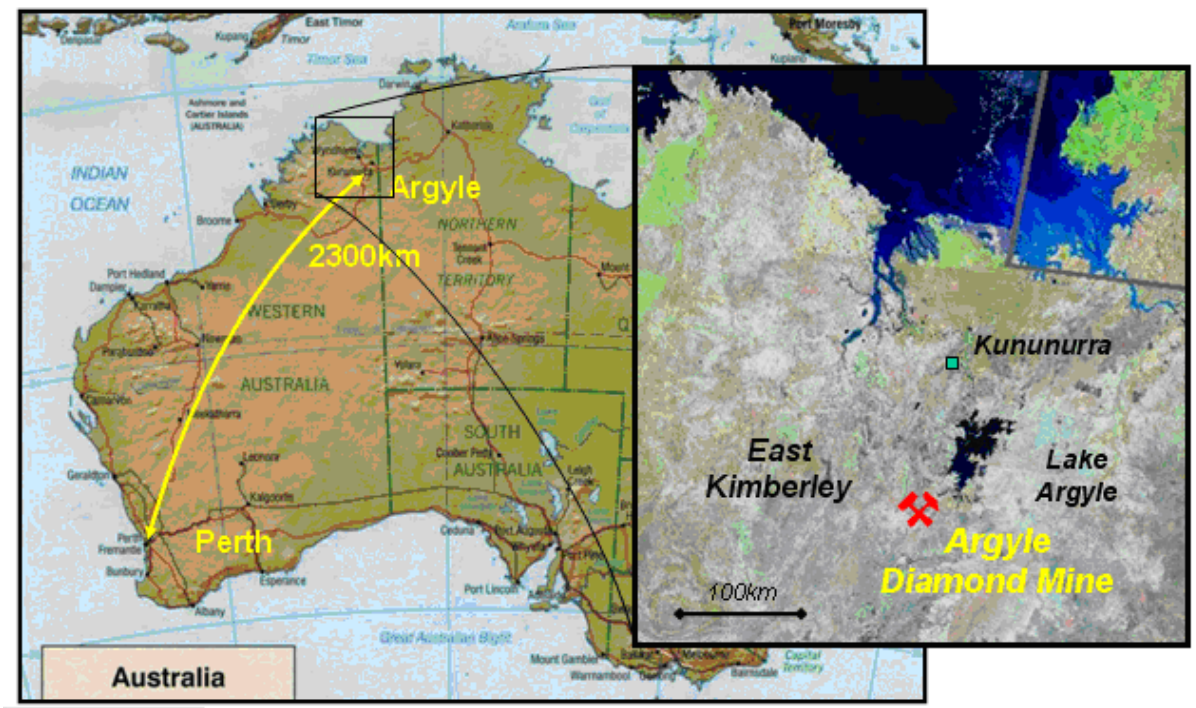

Figure 1 Location of the Argyle Diamond Mine

\section{$2 \quad$ Preceding}

\section{1 Geology}

Local geology of the Argyle region comprises the early Proterozoic Lamboo crystalline basement Complex and the Revolver Creek Formation, the middle Proterozoic Carr Boyd Complex (comprising the Hensman Sandstone, Golden Gate Siltstone and the Lissadell Formation) and the late Proterozoic Antrim Volcanics.

\section{1. 1 Lithology}

Rock types of the Argyle deposit predominately comprise mudstone, quartzite, lamproite (the orebody) and dolerite, as is shown in Figure 2. Breccia zones of the lamproite are common along the ore contacts.
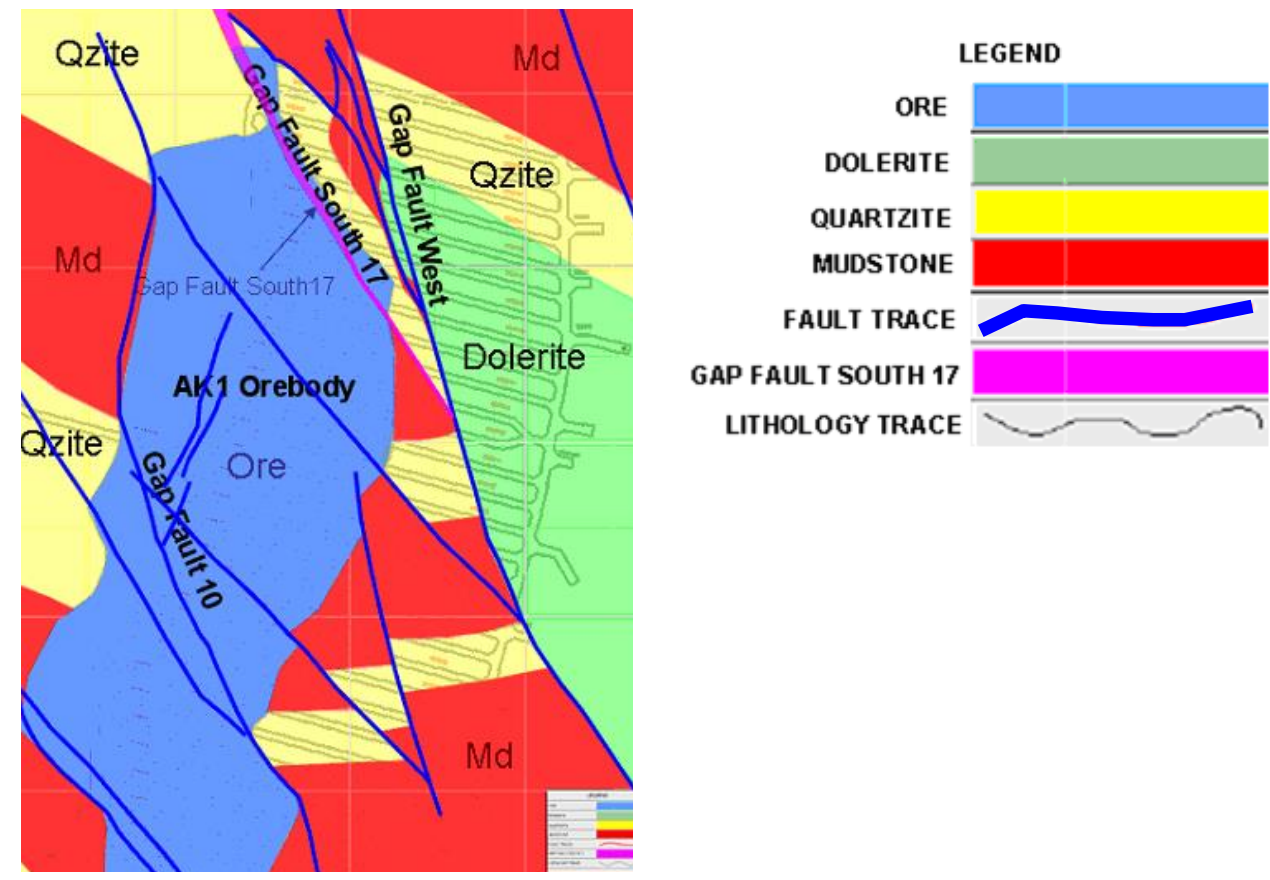

Figure 2 Geology in the undercut level 


\subsubsection{Structure}

The dominant structures of the Argyle deposit are that of the NNW trending gap fault system that has resulted in visible displacement along the elongate margins of the orebody viewed as a series of saw teeth (Rayner, 2005). Other structures have been mapped in the area such as the Razor Ridge Fault that trends $\mathrm{NE}$, however, the gap fault system is the major player and is clearly evident in both the underground development and the open pit, as is shown in Figure 3.

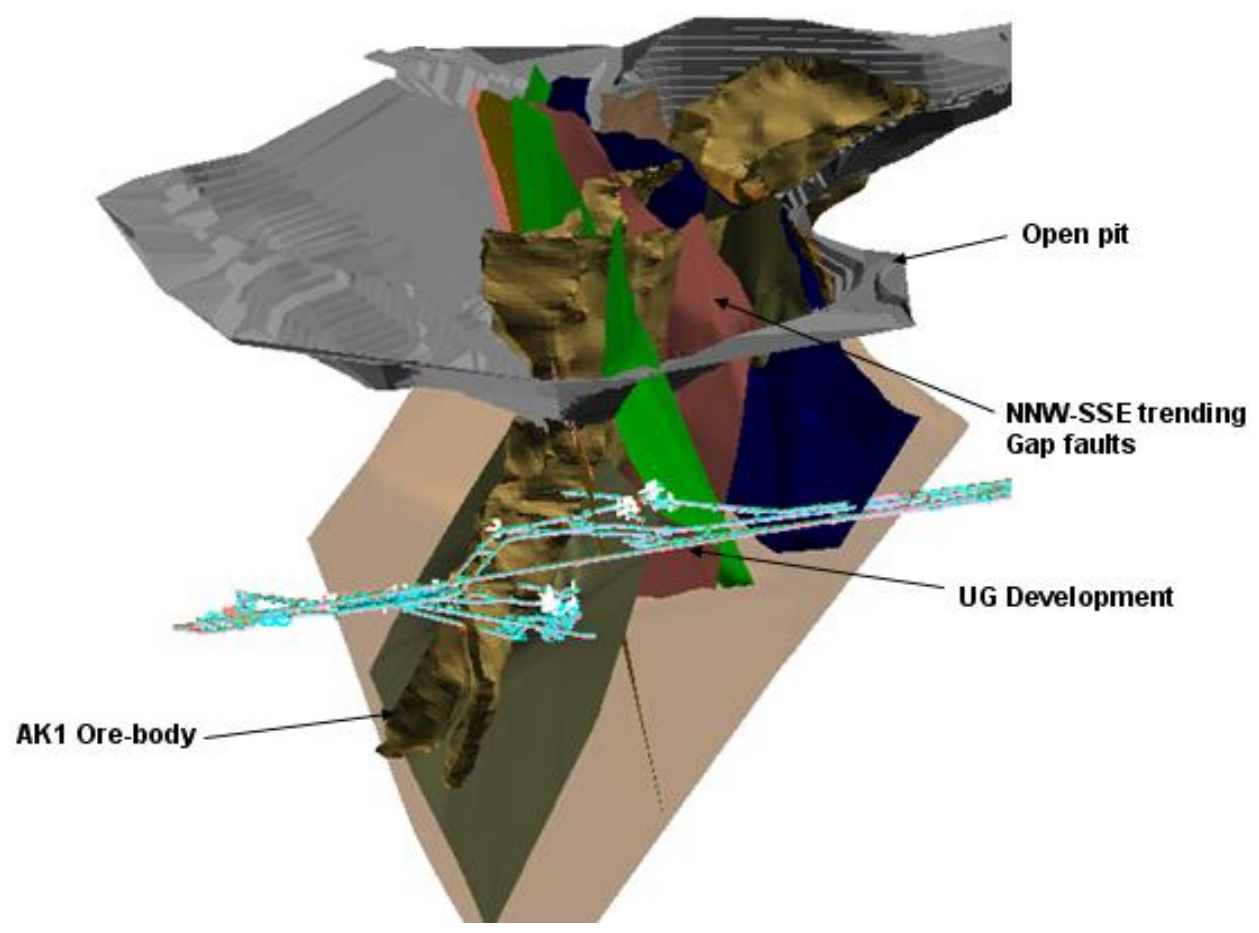

Figure 3 NNW gap fault system and saw tooth margins on the orebody (after Rayner, 2005)

\section{2 Mining}

The life of the Argyle Mine will transcend traditional open pit mining through to underground production by caving methods.

\section{2.1 Open pit}

Production from the Argyle orebody began via an open pit operation at the end of 1985 and has continued for some 25 years to present day. Historic production has been in the order of 25-30 million carats per year. Open pit mining is expected to cease at the end of 2012, with a transition to underground mine production in 2012-2013. A general overview of the current open pit operations is shown in Figure 4.

\section{2.2 Block cave}

Having identified that full depletion of resource/reserves by around 2013 was a real possibility; a feasibility study was undertaken early in 2002 to determine the likelihood of extending the mine life via a block cave operation. Development of the block cave technique comprising an undercut level beneath the target zone of the orebody with subsequent extraction level $15 \mathrm{~m}$ beneath relies largely on a number of block caving parameters such as: rock type, geological structures, stress magnitude and orientation and orebody grade. These all have an influence on caveability and eventual profit of the operation. At full production it is expected that 20,000 to 30,000 tonnes of ore will be processed daily. A three dimensional view showing the position of the future block cave mine with respect to the current open pit operation is shown in Figure 5. 


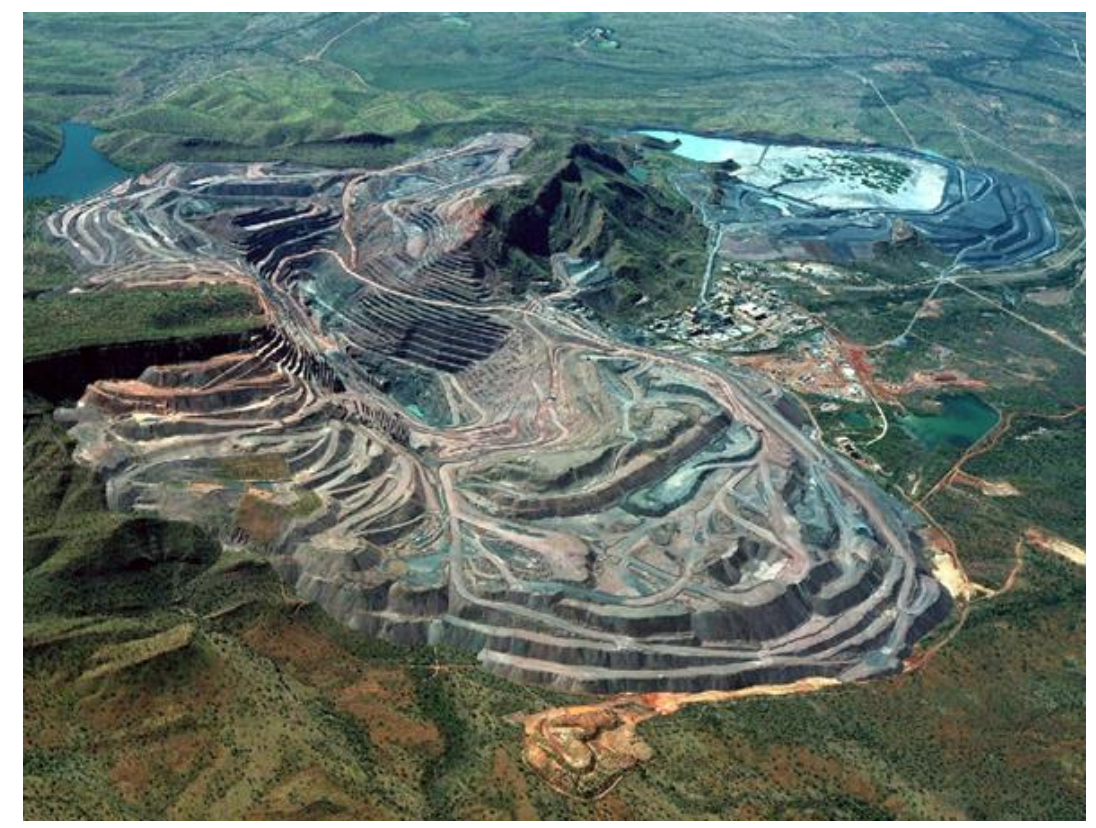

Figure 4 Argyle open pit operations, mining from 1985 to present day

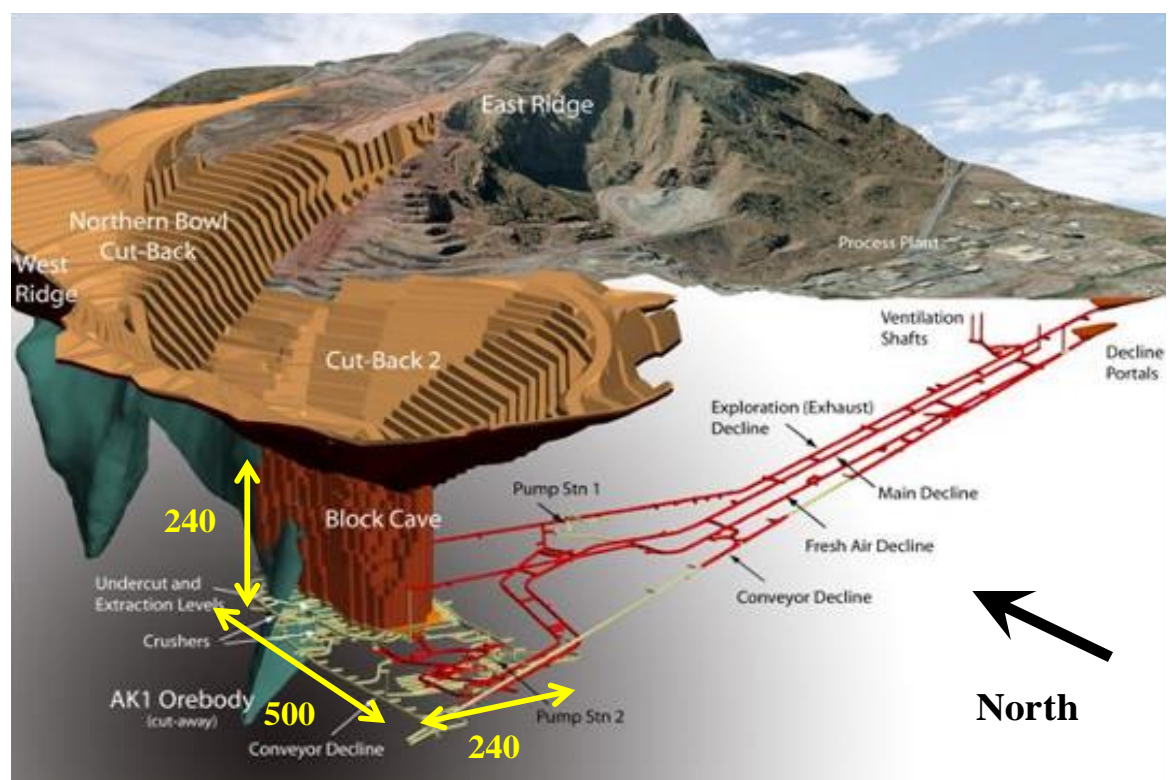

Figure 5 View showing position of the block cave operation with associated development and ore conveyor

Argyle is implementing an advanced undercut technique. In a block cave mine the undercut corresponds to the first stage of caving initiation. The objective of the undercut is to create a continuous zone of broken rock at the base of the block cave orebody and to generate instability above it by allowing gravity and stresses to act in the rock mass, thus sustaining the further stage of cave progress which is cave propagation. A schematic of block cave fundamentals is shown in Figure 6.

Argyle achieved its undercutting milestone event on the 4 October 2008 when the first 'boxhole' and undercutting rings were fired. By the end of May 2011 the undercut has advanced approximately 38,000 $\mathrm{m}^{2}$ out of a total footprint of around $75,000 \mathrm{~m}^{2}$. Additionally, preparation and construction activities had recently commenced in the extraction level in the area that comprises drives ED1 to ED8. 


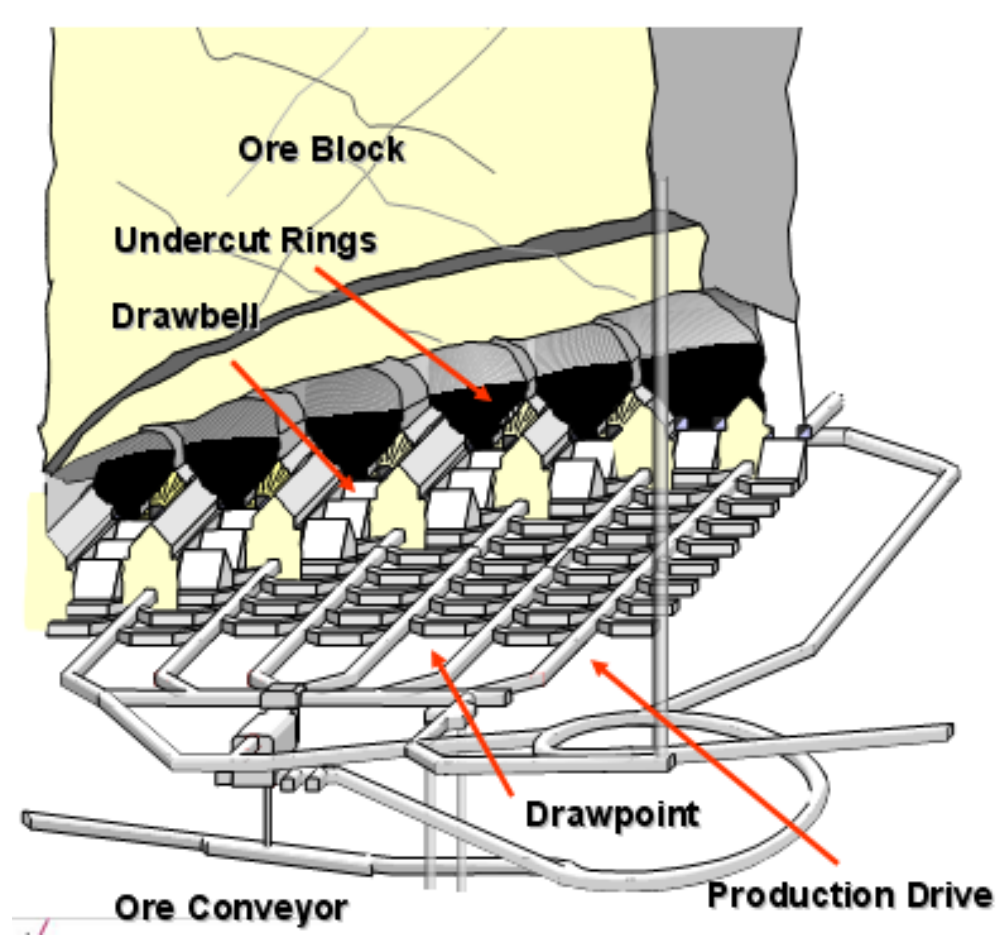

Figure 6 Schematic showing block cave fundamentals

\section{3 Geotechnical condition}

\section{3. 1 Stresses}

The initial stress field and magnitude of stress ratios based on stress measurements is shown in Figure 7 (Clark, 2009).

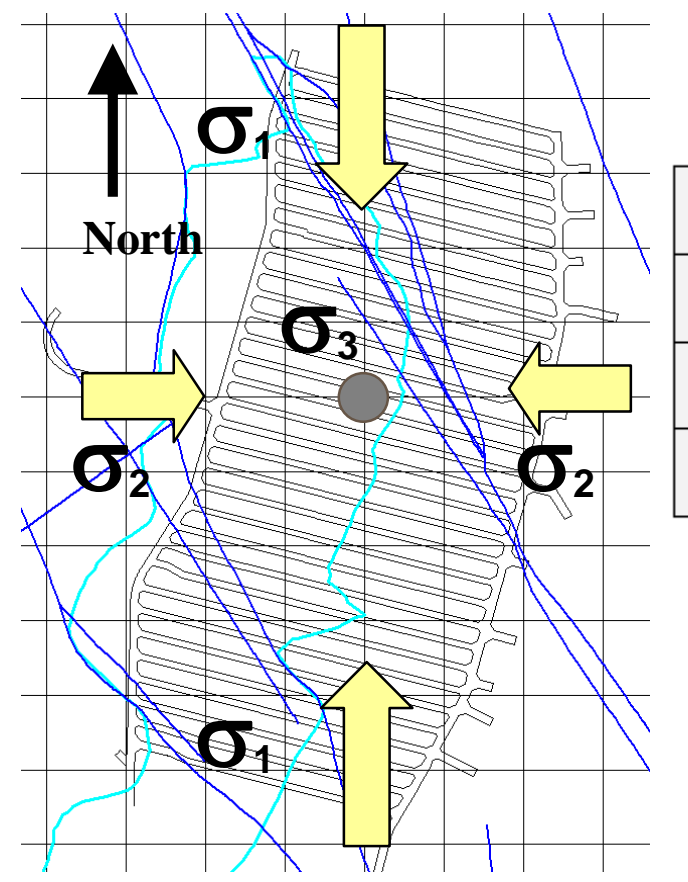

\begin{tabular}{|l|l|l|l|}
\hline $\begin{array}{c}\text { Principal } \\
\text { Stress }\end{array}$ & \multicolumn{1}{|c|}{$\begin{array}{c}\text { Magnitude } \\
\text { (MPa) }\end{array}$} & Orientation & \multicolumn{1}{c|}{ Dip } \\
\hline$\sigma_{1}$ & $=2.5 \sigma_{\mathrm{v}}$ & North-South & Horizontal \\
\hline$\sigma_{2}$ & $=1.5 \sigma_{\mathrm{v}}$ & East-West & Horizontal \\
\hline $\boldsymbol{\sigma}_{3}$ & $=0.027 \mathrm{MPa} / \mathrm{m}$ & Vertical & Vertical \\
\hline
\end{tabular}

Figure 7 Pre-mining stress condition at Argyle Diamonds underground mine

\section{3. 2 Geotechnical domains}

Six main geotechnical domains have been identified in the undercut and extraction levels, as is shown in Figure 8 (modified from Yudanto, 2009). 


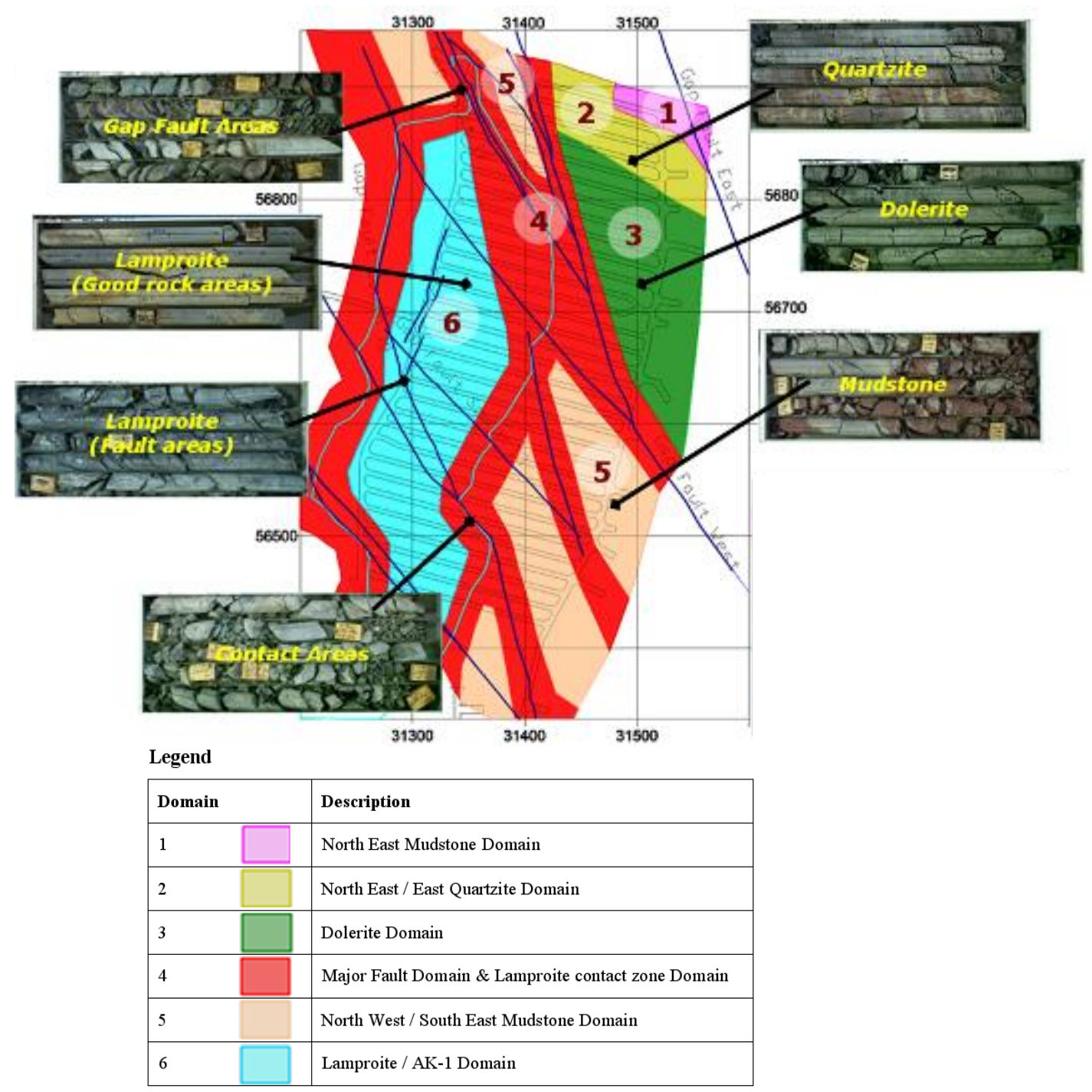

Figure 8 Geotechnical domains in the extraction level

The average rock properties associated with these domains are shown in Table 1.

Table 1 Rock properties (average)

\begin{tabular}{lcccc}
\hline Parameter & \multicolumn{4}{c}{ Rock Units } \\
& Lamproite & Dolerite & Quartzite & Mudstone \\
\hline UCS (MPa) & 85 & 66 & 104 & 35 \\
Young Modulus E (GPa) & 55 & 65 & 52 & 38 \\
Poisson Ratio v & 0.26 & 0.36 & 0.22 & 0.24 \\
RMR $_{1976}$ & 58 & 55 & 59 & $<45$ \\
\hline
\end{tabular}

\section{Convergence monitoring and damage}

Horizontal convergence data collected using a tape extensometer has been recorded in a weekly basis from convergence stations installed every $15 \mathrm{~m}$ along the undercut and extraction level drives. During the undercutting stage, abutment stress has resulted in significant convergence in the zones of weak rock mass strength; e.g. in several undercut drives up to $1.2 \mathrm{~m}$ wall closure has been recorded at the brow. 
A damage assessment methodology based on three relevant parameters: overbreak, water infiltration and support condition has been developed and implemented in ADUP. It has been developed iteratively over a number of months and has been used to comprehensively represent damage conditions as the undercut front advances (Fernandez et al., 2010).

By using the information and analysis of both convergence and damage mapping, an association between these two parameters have been established as is shown in Table 2.

Table 2 Damage classification and convergence

\begin{tabular}{|c|c|c|c|}
\hline \multirow{2}{*}{$\begin{array}{l}\text { Damage } \\
\text { Classification }\end{array}$} & \multirow[t]{2}{*}{ Damage Description } & \multicolumn{2}{|c|}{ Cumulative Convergence } \\
\hline & & $\mathrm{mm}$ & Strain $(\varepsilon)$ \\
\hline Minor & $\begin{array}{l}\text { Minor and spot cracking (<10 mm wide), commencement } \\
\text { of fibrecrete slabbing and/or minor mesh deformation. } \\
\text { Evidence of spot loading in rockbolt plates, primarily in } \\
\text { friction stabilisers. Up to } 0.5 \mathrm{~m} \text { overbreak (during } \\
\text { development) and damp condition may be observed. }\end{array}$ & $<200$ & $<5 \%$ \\
\hline Moderate & $\begin{array}{l}\text { Multiple cracking (10-20 mm wide), fibrecrete slabbing, } \\
\text { exposed embedded mesh with isolated broken welds are } \\
\text { evident. Increased load in rockbolt and cable bolts plates. } \\
\text { Failure of friction stabilisers and isolated failure of resin } \\
\text { bolts plates. Up to } 1 \mathrm{~m} \text { overbreak (during development) } \\
\text { and dripping condition of water influx may be observed. }\end{array}$ & $200-300$ & $5-7 \%$ \\
\hline High & $\begin{array}{l}\text { Multiple cracks (>20 mm wide), multiple fibrecrete } \\
\text { slabbing, failure behind mesh and failure of mesh (broken } \\
\text { welds and strands) are evidenced. Significant and multiple }\end{array}$ & $300-500$ & $7-10 \%$ \\
\hline Very High & $\begin{array}{l}\text { failures of friction and resin bolts and isolated failure of } \\
\text { cable bolts are observed. Up to } 1.5 \mathrm{~m} \text { of overbreak (during } \\
\text { development) and dripping to rain water influx may be } \\
\text { observed. }\end{array}$ & $500-1,000$ & $10-20 \%$ \\
\hline Severe & $\begin{array}{l}\text { Rockfall, collapse and/or massive failure of fibrecrete and } \\
\text { mesh strands occur. High significant cracks and open rock } \\
\text { blocks are observed. Significant and multiple failures of } \\
\text { rockbolts and cable bolts are observed. Overbreak is } \\
\text { usually higher than } 1.5 \mathrm{~m} \text { (during development) and high } \\
\text { flowing/raining water may be observed. }\end{array}$ & $>1,000$ & $>20 \%$ \\
\hline
\end{tabular}

Note: Strain $(\varepsilon)=$ tunnel closure/tunnel diameter $* 100$

Table 2 is suitable for the rock mass conditions encountered in the ADUP only.

An example of convergence/damage condition for early January 2011 is shown in Figure 9.

Information as of early January 2011 indicates that very high damage/convergence is mainly located at drives DD17 and DD18 in the area between the orebody and gap fault system. Severe and localised damage with associate failure of ground support is observed close to the brow position at DD13. High and moderate damage/convergence are located at the proximity of the undercut brows between DD14 and DD18, and in the vicinity of geological features such as the orebody contact, gap faults and mudstone rocks at the south of DD16 close to the Fw aAccess. Minor damage is expanding towards the south following the orebody contour and fault systems. Note that black coloured circles shown in Figure 9 represent the location of convergence stations every $15 \mathrm{~m}$ in the side walls. 


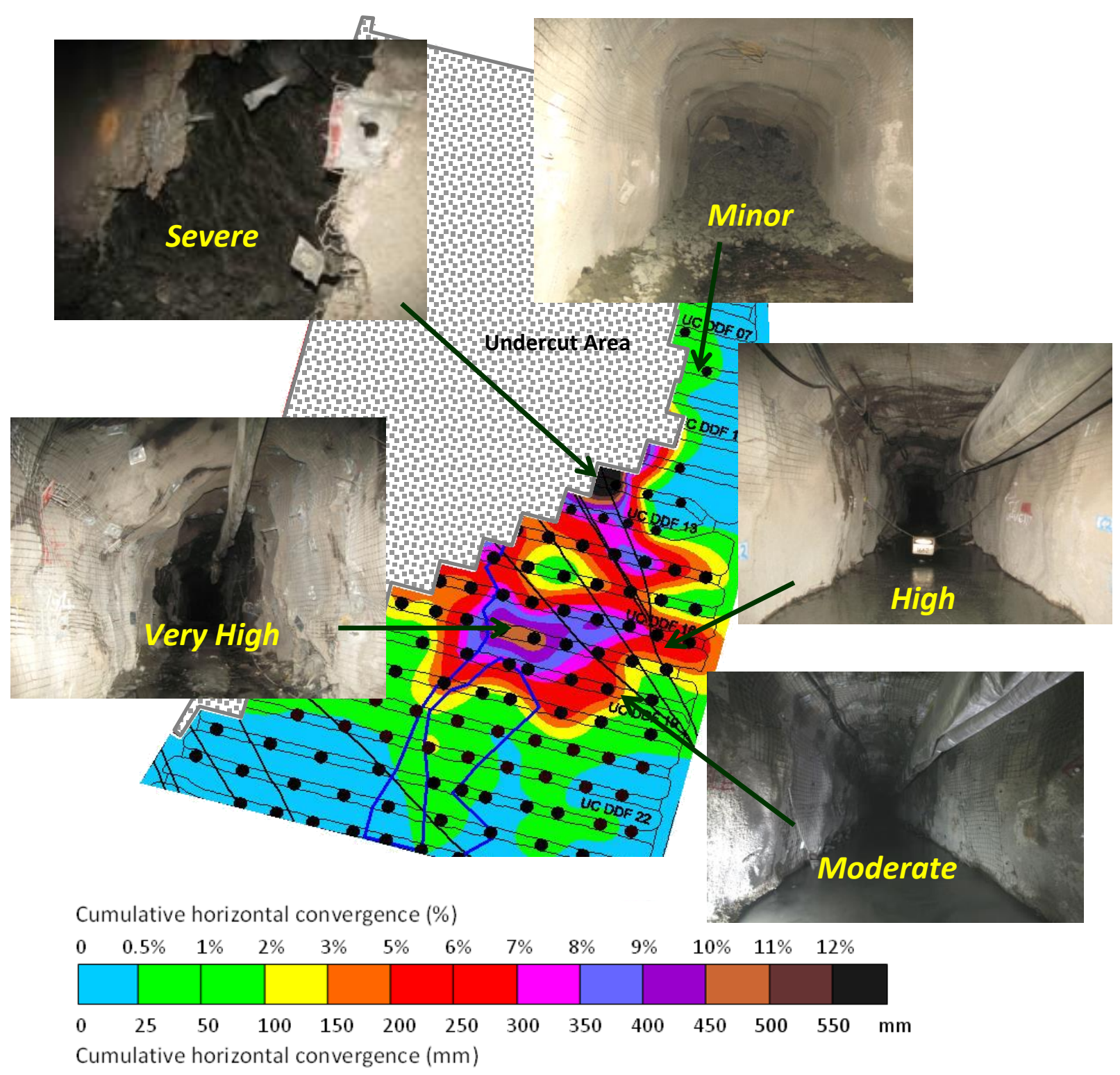

Figure 9 Representation of convergence and damage in the undercut level, early January 2011

Weekly convergence data, analysed in conjunction with monthly damage mapping of drives have provided relevant information regarding the rock mass behaviour and ground support performance. Iterative assessments indicate that distinctive ground support regimes can be determined to cope with the high squeezing ground conditions monitored in the undercut level. Preliminary, this may suggest that a strategic approach may be implemented for both ground support optimisation and drives stability purpose.

\section{$4 \quad$ Strategic approach for ground support in the undercut level}

During the drives development at the undercut level, three main ground support regimes were considered: regular, medium and heavy support. This approach is described in Table 3 and Figure 10. 
Table 3 Classification of ground support regimes at the undercut level

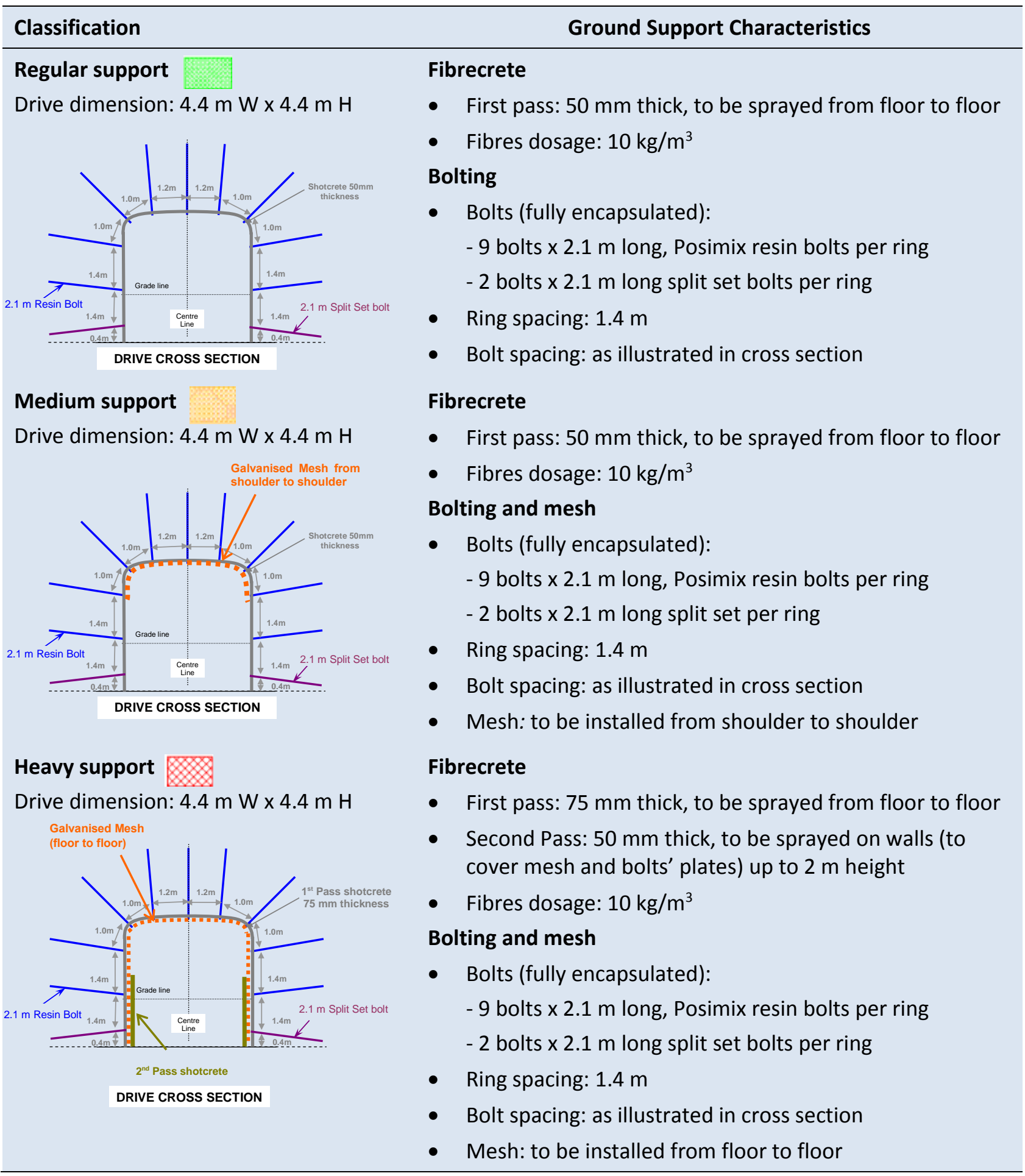

Additional ground support consisting of cable bolts at the backs of intersections and osro straps pinned with $2.1 \mathrm{~m}$ long rockbolts and/or cable bolts, on pillars at the footwall access (east) and in certain areas of the hangingwall access (west), were also installed at the undercut level.

Early during undercutting, high convergence and damage were observed and monitored at the undercut level excavations, especially in poor rock mass areas represented by mudstone, gap fault and orebody contact zones (previously described as Geotechnical Domains 4 and 5 in Figure 8). In order to maintain the stability of those areas, additional ground support which comprises de-bonded cable bolts on walls and backs of excavations, combined with osro straps has been implemented. 


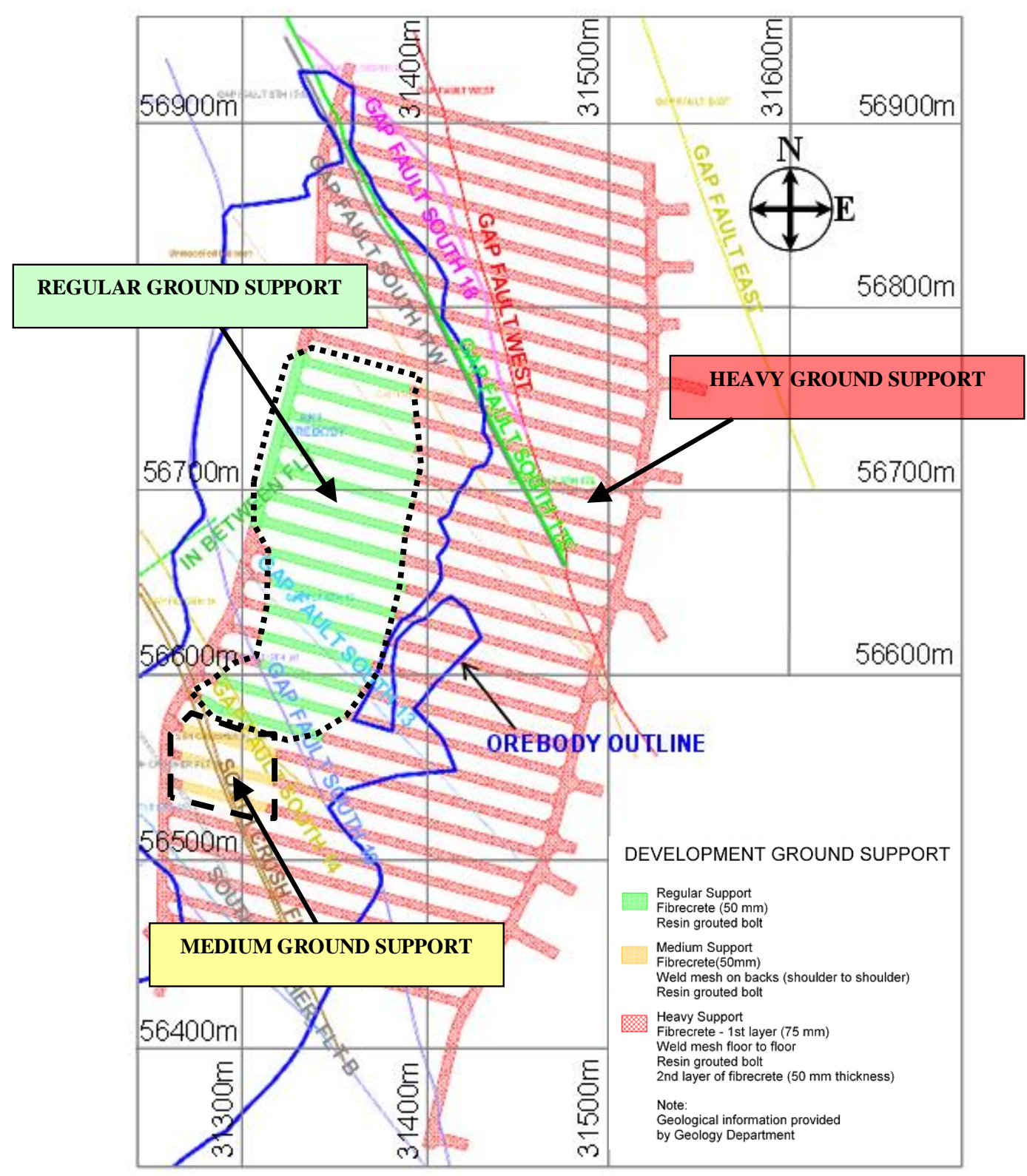

Figure 10 Ground support recommendations in the undercut level

Simultaneously, damage and convergence information was collected and analysed to provide a better understanding of the rock mass stability conditions with the aim of optimising ground support regimes. A process map flow which describes how the strategy had changed from a tactical into a strategic approach is shown in Figure 11. The additional ground support scheme (plan view) is shown in Figure 12.

In the areas where significant squeezing was predicted, the heavy-yielding support was complemented with a series of undercut guidelines for managing convergence. These guidelines comprise: an adequate rate of advance (at least $10 \mathrm{~m} / \mathrm{month}$ ), undercut geometry - concave shape to solid (Brown, 2002), lead-lags ( $\leq 12 \mathrm{~m}$ in fair ground and $\leq 8 \mathrm{~m}$ in poor ground), and undercut front/face oriented perpendicular to the gap fault system. 


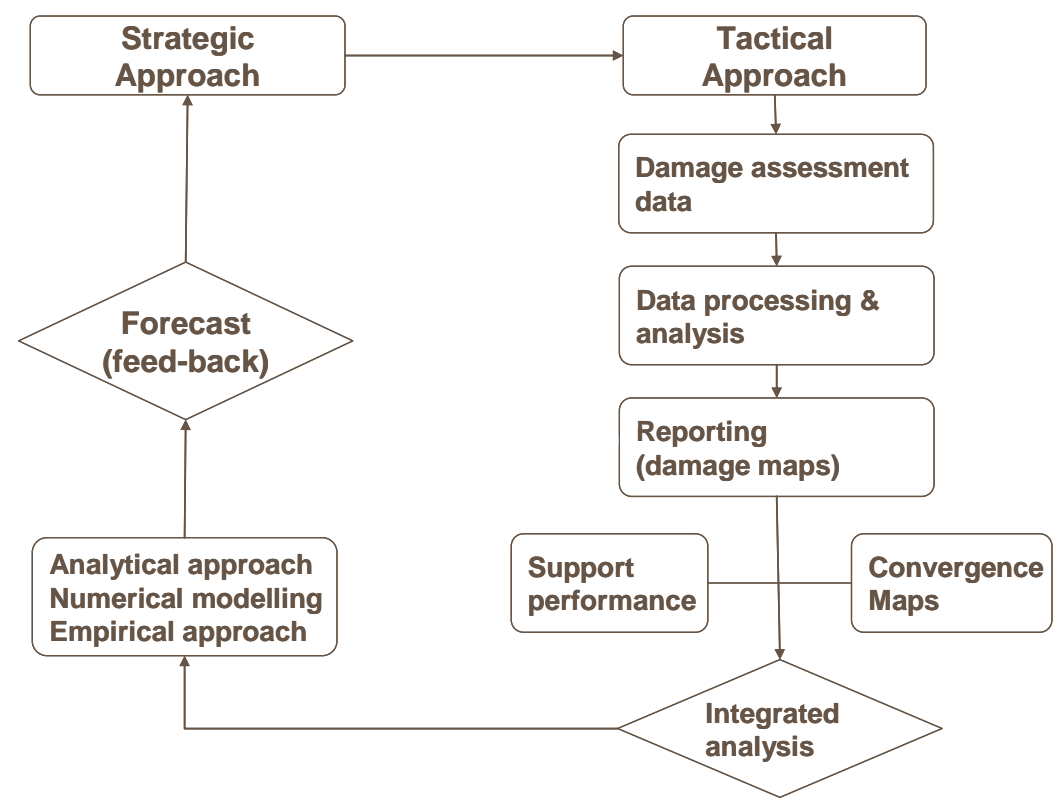

Figure 11 Process map describing the overall ground stability strategy in the undercut level

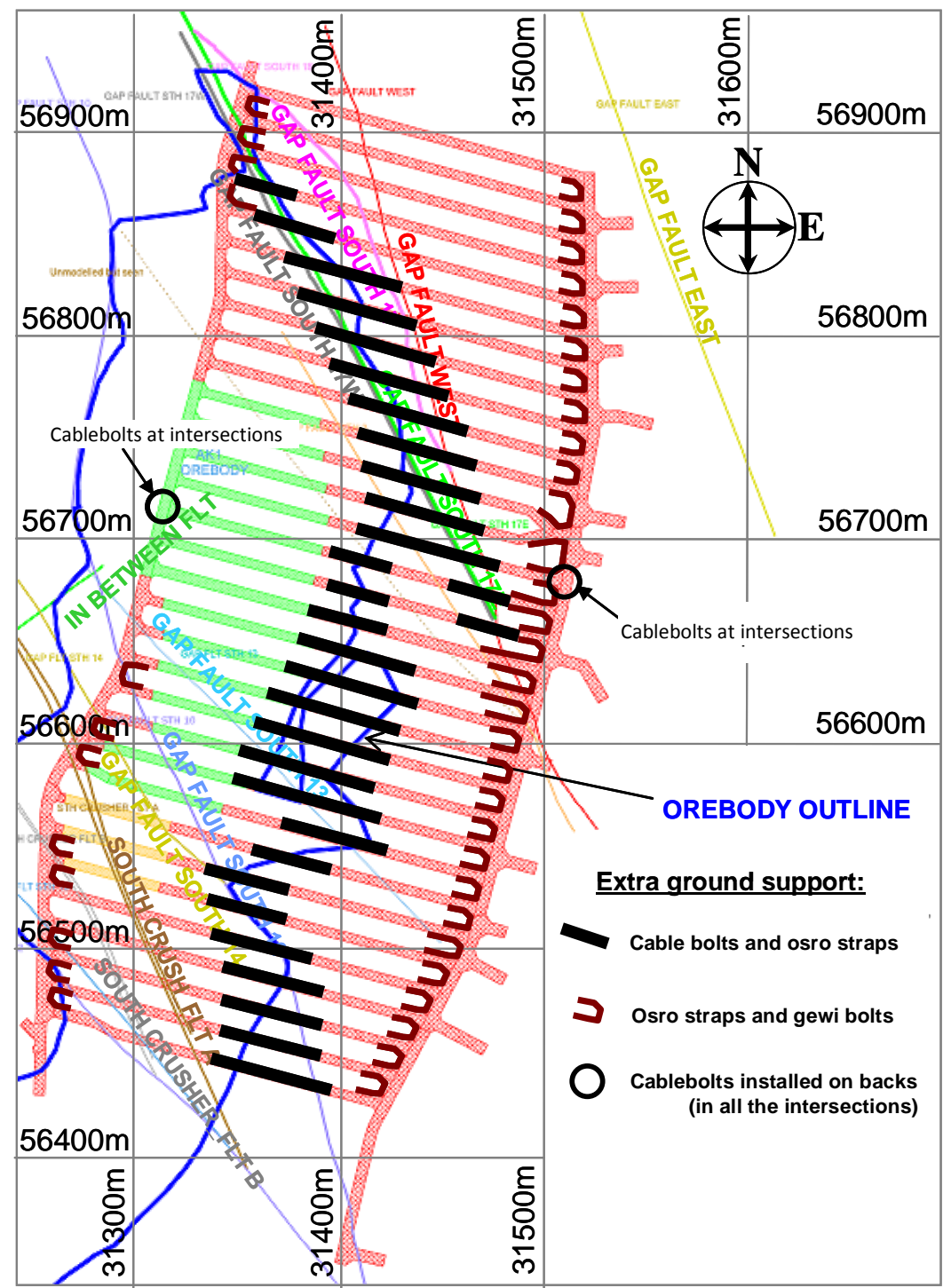

Figure 12 Additional ground support recommended for the undercut level 


\section{1 Graphical representation of convergence}

To develop a correlation between convergence and rock mass, an analytical approach is chosen. For this particular example of convergence application, a number of convergence stations were chosen at the undercut level. Convergence data was analysed for the period June 2009 to early January 2011, which represents an average undercutting rate of approximately $1,600 \mathrm{~m}^{2} / \mathrm{month}$. The distance measured perpendicularly from the undercut front to each convergence station was registered for each monitored date. Information regarding the geological strength index (GSI) (Hoek and Marinos, 2000) was included in the analysis. This was obtained from geotechnical and geological back maps of the development faces. Finally, the results were graphically plotted and correlation between the input data and the best-fit graphs was established for each monitoring station.

Three basic parameters have been considered in this analysis, namely cumulative convergence, distance of undercut front and rock mass classification (GSI).

Convergence data is collected weekly and stored in a database. Cumulative convergence indicates the history of the deformation from the day the data was first collected.

Distance to the undercut front is measured perpendicularly from the undercut front to each convergence station at the time of monitoring.

An example of graphical representation of the data is shown in Figure 13. The steps of analysis are as follows:

- Step 1: A cumulative convergence (CC) versus distance to undercut front (DUC) graph is plotted. For illustration purposes, convergence stations at DD15 are chosen. The input data are described in Figure 13.

- Step 2: A best-fit graph for the input data is represented, as is shown in Figure 13. The equations and correlations for the best-fit graphs are described in Table 4.

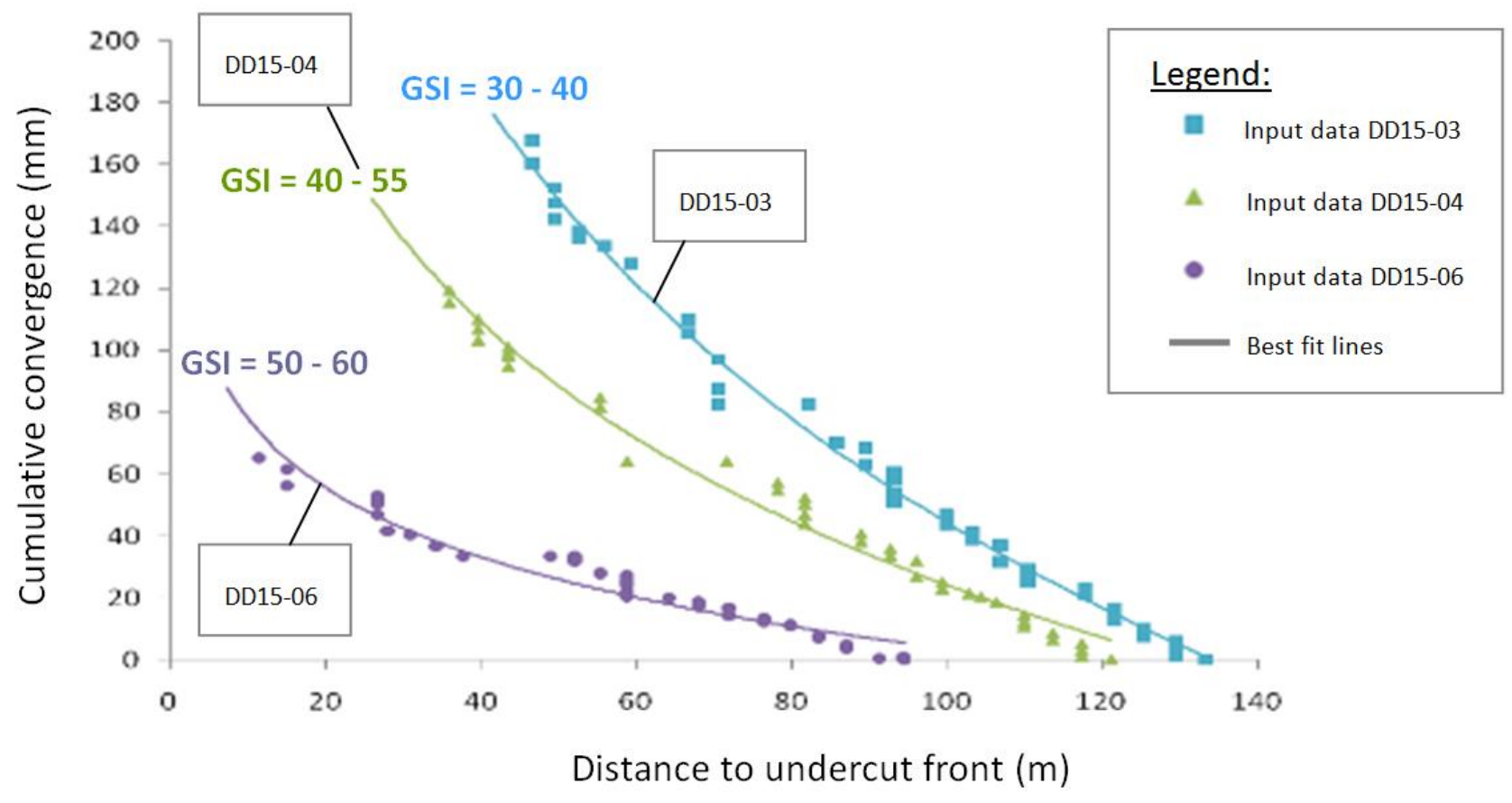

Figure 13 Example of graphical representation of convergence at DD15 
Table 4 Equations and correlations for the best-fit graphs

\begin{tabular}{ccc}
\hline Convergence Station & Equation & Correlation $-\mathbf{R}^{\mathbf{2}}$ \\
\hline DD15-03 & $y=-150.7 \ln (x)+738.2$ & $99.2 \%$ \\
DD15-04 & $y=-92.68 \ln (x)+451.01$ & $98.1 \%$ \\
DD15-06 & $y=-61.65 \ln (x)+280.06$ & $94.2 \%$ \\
\hline
\end{tabular}

From Table 4, it can be deduced that the relationship between the two parameters (CC and DUC), can be represented as: $C C=A \ln (D U C)+B$, with $A$ and $B$ parameters describing different values as per the best-fit graphs.

With the purpose of obtaining a statistically representative sample of the stability behaviour for the undercut drives, the analysis can be extended to a significant portion of the undercut level. In this case, data collected from drives UCDD14 to UCDD20 were considered. This information is shown in Table 5 and Table 6.

Table 5 Best-fit parameters associated to convergence values

\begin{tabular}{|c|c|c|c|c|c|}
\hline \multirow{2}{*}{$\begin{array}{l}\text { Convergence } \\
\text { Stations }\end{array}$} & \multirow[t]{2}{*}{ Rock Type } & \multirow[t]{2}{*}{ GSI } & \multicolumn{3}{|c|}{ Equation $y=A \ln (x)+B$} \\
\hline & & & A & B & $\mathbf{R}^{\mathbf{2}}$ \\
\hline DD14-03 & Dolerite & $40-45$ & -125.40 & 599.60 & $97.4 \%$ \\
\hline DD14-04 & Quartzite & $45-55$ & -77.05 & 366.35 & $96.7 \%$ \\
\hline DD14-06 & Quartzite & $55-65$ & -32.76 & 150.53 & $96.5 \%$ \\
\hline DD15-03 & Mudstone & $30-40$ & -150.70 & 738.20 & $99.2 \%$ \\
\hline DD15-04 & Quartzite and Mudstone & $40-55$ & -92.68 & 451.01 & $98.1 \%$ \\
\hline DD15-06 & Quartzite & $50-60$ & -61.65 & 280.06 & $94.2 \%$ \\
\hline DD16-02 & Mudstone & $10-15$ & -368.80 & $1,861.80$ & $94 \%$ \\
\hline DD16-04 & Mudstone & $10-20$ & -385.10 & $1,918.20$ & $98.8 \%$ \\
\hline DD16-05 & Mudstone & $20-30$ & -278.90 & $1,357.50$ & $99.2 \%$ \\
\hline DD17-01 & Mudstone & $25-35$ & -189.30 & 941.60 & $94.7 \%$ \\
\hline DD17-02 & Mudstone & $30-40$ & -134.40 & 666.17 & $97.5 \%$ \\
\hline DD17-03 & Mudstone & $15-20$ & -346.00 & $1,685.10$ & $98.6 \%$ \\
\hline DD17-04 & Mudstone & $15-25$ & -379.80 & $1,821.00$ & $98.5 \%$ \\
\hline DD17-05 & Mudstone & $15-20$ & -439.80 & $2,074.00$ & $99.3 \%$ \\
\hline DD17-06 & Mudstone & $25-32$ & -342.40 & $1,568.10$ & $98.8 \%$ \\
\hline DD18-01 & Mudstone & $35-40$ & -124.20 & 611.84 & $97.5 \%$ \\
\hline DD18-04 & Mudstone & $15-20$ & -486.40 & $2,218.80$ & $97.7 \%$ \\
\hline DD19-02 & Mudstone & $28-35$ & -167.10 & 819.57 & $97.9 \%$ \\
\hline DD19-03 & Mudstone & $10-15$ & -481.80 & $2,302.00$ & $98.4 \%$ \\
\hline DD19-05 & Lamproite & $45-50$ & -103.60 & 470.03 & $98.2 \%$ \\
\hline DD20-02 & Quartzite and Mudstone & $40-50$ & -104.20 & 506.81 & $91.5 \%$ \\
\hline
\end{tabular}


Table 6 Rock properties and GSI at convergence stations

\begin{tabular}{|c|c|c|c|c|c|}
\hline $\begin{array}{l}\text { Convergence } \\
\text { Station }\end{array}$ & Cut \# & Rock Type & Structure & $\begin{array}{l}\text { Surface } \\
\text { Conditions }\end{array}$ & GSI \\
\hline DD14-03 & UL1704/1706 & Dolerite & Very blocky & Fair & $40-45$ \\
\hline DD14-04 & UL1695/1697 & Quartzite & Blocky & Fair to good & $45-55$ \\
\hline DD14-06 & UL1670/1672 & Quartzite & Blocky & Good & $55-65$ \\
\hline DD15-03 & UL1718/1720 & Mudstone & Blocky/disturbed, seamy & Poor to fair & $30-40$ \\
\hline DD15-04 & UL1712/1713 & $\begin{array}{l}\text { Quartzite \& } \\
\text { Mudstone }\end{array}$ & Very blocky & Fair to good & $40-55$ \\
\hline DD15-06 & UL1689/1690 & Quartzite & Blocky & Good & $50-60$ \\
\hline DD16-02 & UL541/1741 & Mudstone & Disintegrated & Poor to very poor & $10-15$ \\
\hline DD16-04 & UL1749/1751 & Mudstone & $\begin{array}{l}\text { Disintegrated, partially } \\
\text { laminated/sheared }\end{array}$ & Poor to very poor & $10-20$ \\
\hline DD16-05 & UL1734/1736 & Mudstone & $\begin{array}{l}\text { Blocky/disturbed, seamy, } \\
\text { partially disintegrated }\end{array}$ & Poor & $20-30$ \\
\hline DD17-01 & UL451/454 & Mudstone & $\begin{array}{l}\text { Blocky/disturbed, seamy, } \\
\text { partially disintegrated }\end{array}$ & Poor to fair & $25-35$ \\
\hline DD17-02 & UL464/457 & Mudstone & Blocky/disturbed, seamy & Poor to fair & $30-40$ \\
\hline DD17-03 & UL478/482 & Mudstone & Disintegrated & Poor to very poor & $15-20$ \\
\hline DD17-04 & UL494/497 & Mudstone & Disintegrated & Poor to very poor & $15-25$ \\
\hline DD17-05 & UL511/514 & Mudstone & Disintegrated & Poor to very poor & $15-20$ \\
\hline DD17-06 & UL378/380 & Mudstone & $\begin{array}{l}\text { Blocky/disturbed, seamy, } \\
\text { partially disintegrated }\end{array}$ & Poor to fair & $25-32$ \\
\hline DD18-01 & UL1764/1765 & Mudstone & Blocky/disturbed, seamy & Poor to fair & $35-40$ \\
\hline DD18-04 & UL1826/1829 & Mudstone & $\begin{array}{l}\text { Very blocky to } \\
\text { disintegrated }\end{array}$ & Poor to very poor & $15-20$ \\
\hline DD19-02 & UL1783/1785 & Mudstone & $\begin{array}{l}\text { Blocky/disturbed, seamy, } \\
\text { partially disintegrated }\end{array}$ & Poor to fair & $28-35$ \\
\hline DD19-03 & UL1809/1812 & Mudstone & $\begin{array}{l}\text { Disintegrated, partially } \\
\text { laminated/sheared }\end{array}$ & Poor to fair & $10-15$ \\
\hline DD19-05 & UL1874/1877 & Lamproite & Very blocky & Fair to good & $45-50$ \\
\hline DD20-02 & UL1958/1962 & $\begin{array}{l}\text { Quartzite \& } \\
\text { Mudstone }\end{array}$ & Very blocky & Fair & $40-50$ \\
\hline
\end{tabular}

\section{2 Convergence nomogram and trigger-actions response plans}

The information previously analysed regarding convergence, distance to the undercut front and rock mass data (GSI) is graphically compiled in Figure 14.

The information represented in Figure 14 is compiled with Table 2 to create a nomogram which links: rock mass data, convergence, distance to undercut front, level of damage and trigger-actions response plans (TARPS). This nomogram is shown in Figure 15. 


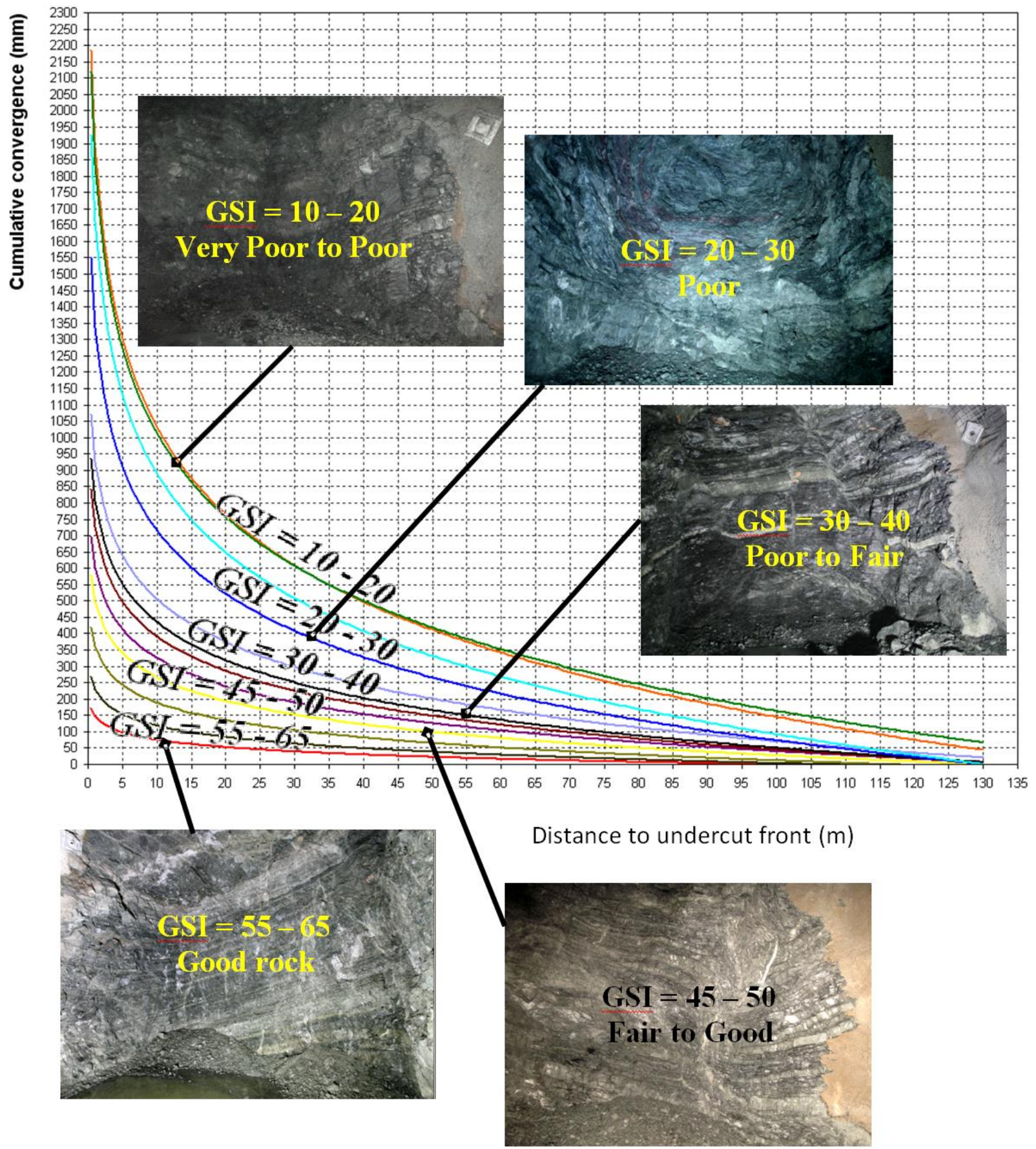

Figure 14 Nomogram representing cumulative convergence, distance to the undercut front and rock mass classification (GSI)

The nomogram (Figure 15) shows it is possible to estimate the criticality of damage with regard to each particular rock mass condition (GSI). Hence, the following assertions:

- The maximum expected convergence for good rock mass (GSI =55-65), would be in the order of 200-250 mm. In this case, minor to moderate damage may be expected, which is likely to occur in close proximity of the undercut face $(5 \mathrm{~m})$, at the brow.

- With fair to good rock mass (GSI $=45-50$ ), the maximum expected convergence would be in the order of $500 \mathrm{~mm}$ (high damage scenario). This damage would extend 5-8 $\mathrm{m}$ away from the undercut face, at the proximity of the brow. 
- Poor to fair rock mass (GSI = 30-40), may result on a maximum convergence in the order of $1,000 \mathrm{~mm}$, which represents very high damage. This damage would commence $10 \mathrm{~m}$ away from the undercut face.

- With poor rock mass condition (GSI = 20-30), the maximum likely convergence would be in excess of 1,000 $\mathrm{mm}$ - which indicates severe damage-and it may be expected to occur in close proximity of the undercut face $(<5 \mathrm{~m})$, at the brow. For this rock type, very high damage extends around $20-25 \mathrm{~m}$ whilst high damage extends up to $50 \mathrm{~m}$ away from the undercut front.

- The maximum expected convergence for very poor to poor rock mass (GSI $=10-20$ ), would be in excess of $1,000 \mathrm{~mm}$ (severe damage), and it may be expected to occur $10 \mathrm{~m}$ away from the undercut face. For this rock type, very high damage extends around $40 \mathrm{~m}$ whilst high damage is located up to $70 \mathrm{~m}$ away from the undercut front.

- The convergence nomogram allows 'predicting', with an acceptable level of accuracy, the severity of damage by using early/preliminary convergence data for a particular area. Hence, it provides a comprehensive understanding of the rock mass and damage relationship which allows undertaking a strategic approach with regard to ground support-reinforcement and undercut advance.

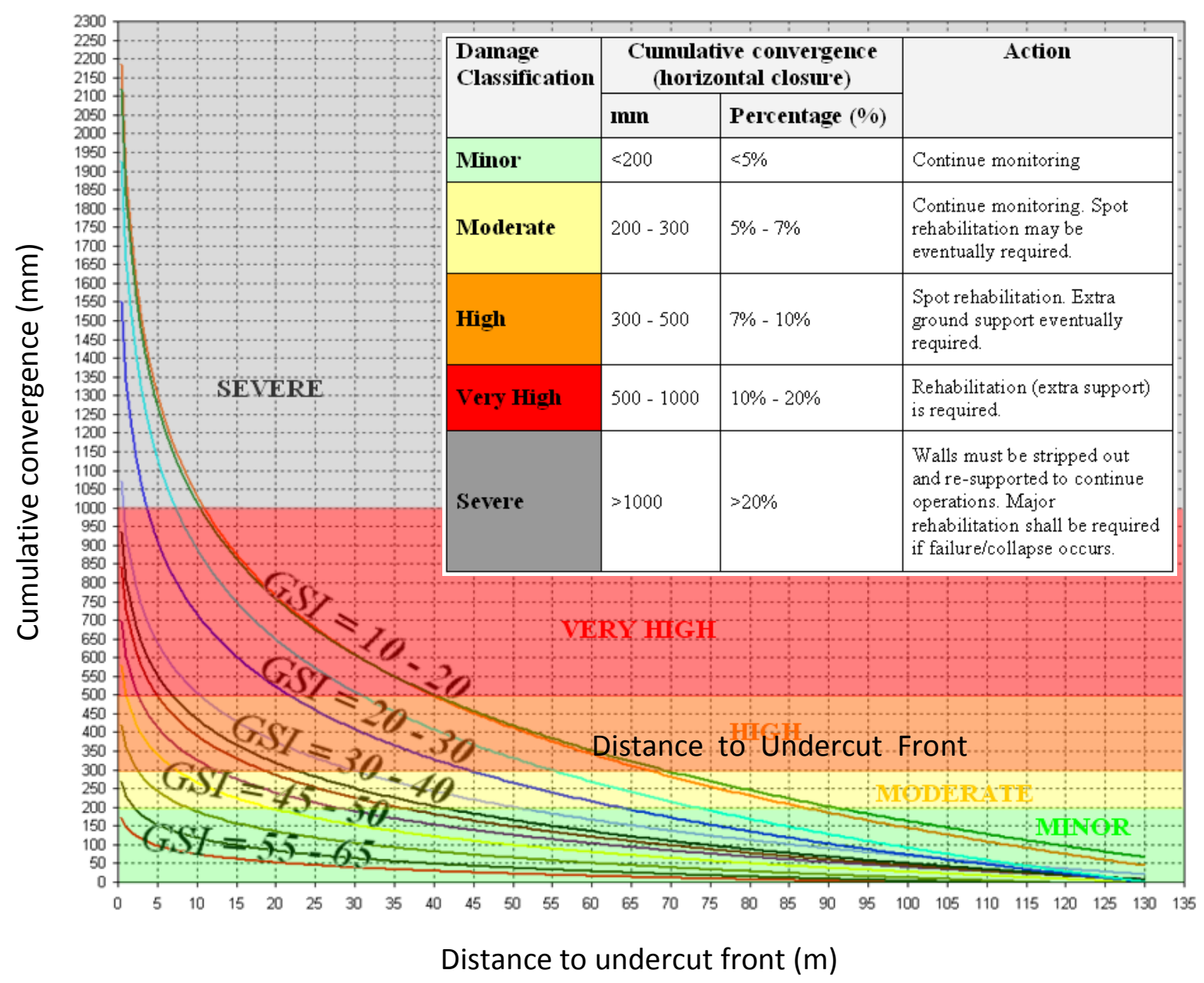

Figure 15 Nomogram representing cumulative convergence, distance to the undercut front, rock mass classification (GSI) and TARPS 


\section{3 Example of application}

The practicality of the previous nomogram is exemplified as follows: Cumulative convergence, distance to the undercut front and rock mass data (GSI) were recorded at two monitoring stations, designated as DD11-06 and DD12-09, as is shown in Table 7.

Table 7 Example of convergence monitoring data (undercut level)

\begin{tabular}{cccc}
\hline $\begin{array}{c}\text { Convergence } \\
\text { Station }\end{array}$ & GSI & $\begin{array}{c}\text { Distance to UC } \\
(\mathbf{m})\end{array}$ & $\begin{array}{c}\text { Cumulative } \\
\text { Convergence (mm) }\end{array}$ \\
\hline DD11-06 & GSI = 30-40 & 88.59 & 0 \\
& & 75.53 & 18.95 \\
& & 67.72 & 29.14 \\
& & 60.31 & 44.4 \\
\hline DD12-09 & 50.3 & 85.31 \\
& GSI=20-30 & 41.22 & 130.44 \\
& & 30.69 & 199.67 \\
\hline & & 101.6 & 10.04 \\
& & 90.08 & 54.88 \\
& & 79.23 & 83.58 \\
& & 69.4 & 141.8 \\
& & 58.13 & 200.22 \\
& & 48.33 & 247.5 \\
& & 35.28 & 304.58 \\
& & 26.04 & 401.01 \\
\hline
\end{tabular}

These convergence stations are depicted in grey and black squares on the nomogram (Figure 16).

The expected convergence scenario is compared with the actual deformation at the previously mentioned locations. The example reflects an estimated cumulative convergence around $400 \mathrm{~mm}$ when the undercut front is $12 \mathrm{~m}$ close to convergence station DD11-06; with the actual value in the order of $350 \mathrm{~mm}$. Cumulative convergence of approximately $700 \mathrm{~mm}$ at the proximity of the undercut face $(10 \mathrm{~m})$ is predicted for DD12-09. The actual figure indicates $600 \mathrm{~mm}$ of convergence for this scenario. In both cases, the difference between the estimated and actual figures is around $15 \%$ which indicates an acceptable accuracy of 'prediction'.

Additionally, a maximum likely convergence of $700 \mathrm{~mm}$ and $1,000 \mathrm{~mm}$ is predicted for DD11-06 and DD12-09, respectively. The damage condition may be very high when the undercut front is $5-20 \mathrm{~m}$ close to the undercut face, which suggests that spot rehabilitation with extra ground support would be eventually required.

\section{Conclusions}

The implementation of this strategic approach to ground support installation and timing at ADUP is crucial to the stability of the undercut drill drives. The convergence nomograms have been proven to successfully predict the damage at monitored points in the drill drives. This data, when used in conjunction with GSI, can effectively be used for early identification of areas likely to experience high convergence and damage. This system allows these areas to be adequately supported well ahead of any damage. 
The installation of the heavier ground support regime, in conjunction with effective implementation of undercut guidelines and rules, has demonstrated that high squeezing ground conditions can be manageable. However, failure to do so could lead to uncontrolled damage, collapse and abandonment of undercut areas, and subsequently compromising the integrity of the extraction level.

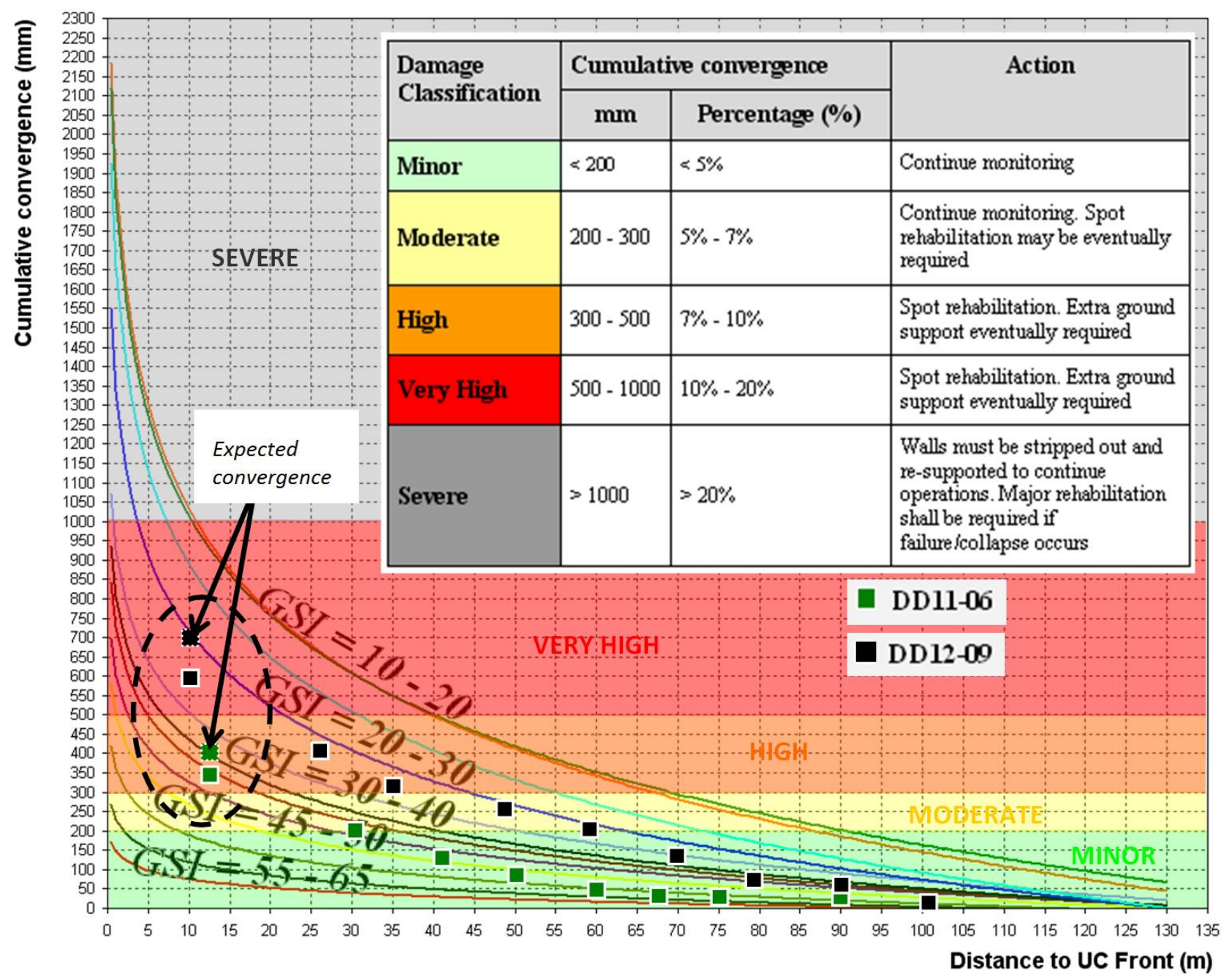

Figure 16 Example of application of predictive convergence on the nomogram

\section{Acknowl edgements}

The writers wish to acknowledge the permission from Rio Tinto Technology and Innovation and the Argyle Diamonds Underground Project to publish this paper.

\section{References}

Brown, E.T. (2002) Block Caving Geomechanics, Julius Kruttschnitt Mineral Research Centre and the University of Queensland. Clark, I. (2009) Review of ADM stress measurements data, GEONET Consulting Group, Report submitted to Rio Tinto.

Fernandez, F., Evans, P. and Gelson, R. (2010) Design and implementation of a damage assessment system at Argyle Diamonds Block Cave Project, in Proceedings 2nd International Symposium on Block and Sublevel Caving (Caving 2010), Y. Potvin (ed), 20-22 April 2010, Perth, Australia, Australian Centre for Geomechanics, Perth, pp. 65-81.

Hoek, E. and Marinos, P. (2000) Predicting tunnel squeezing, Tunnels and Tunnelling International, Part I: November 2000, Part 2: December 2000.

Rayner, M. (2005) Argyle Diamond Mine, Geological Model Update.

Yudanto, W. (2009) Predictive ground support for undercut and extraction levels, in Geotechnical Department, Argyle Diamonds Underground Project - internal report (NFR-GEO-001), Rio Tinto. 